\title{
HISTORICAL NOTES ON THE SOUND STRUCTURE OF THE HILL MARI LANGUAGE AS AN IMPORTANT ASPECT IN LANGUAGE EDUCATION
}

\author{
Zoya Zorina ${ }^{1}$, Nadezhda Krasnova ${ }^{2^{*}}$ and Tatyana Yantsukova ${ }^{3^{*}}$ \\ ${ }^{1}$ Prof. Dr., Mari State University, The Russian Federation, zorinazoia@mail.ru \\ ${ }^{2}$ Asoc. Prof. Dr., Mari State University, The Russian Federation, krasnovanadezhda5@yandex.ru \\ ${ }^{3}$ Asoc. Prof. Dr., Mari State University, The Russian Federation, stv79@bk.ru \\ ${ }^{*}$ Corresponding Author
}

\begin{abstract}
In modern methodological science, the term "language education" is widely used. It has a multidimensional character and involves the consideration of education in the field of languages as a value, process, result and system. Language education as a value is expressed in relation to it on the part of the state, society and the individual.
\end{abstract}

Consequently, one can speak of language education as a state, social and personal value. That is why the importance of this article includes regarding sound structure of the Hill Mari language for future school teachers.

It is known that the language can also play the role of a state or local language. For example, the Russian language in Russia acts as the state language; local languages include any language used in a specific region, region or district of a particular country. Hill Mari is one of them which is spoken only in two regions of the Republic of Mari El.

In the given article the authors try to review and analyze all available information about the Hill Mari language in the pre-literate period - until 1920, when the Mari alphabet was officially introduced.

It is important to know for the future teachers that two problems should be noted regarding the Hill Mari: 1) it remains uninvestigated; 2) it is on the verge of extinction. According to the UNESCO Red List of Languages, the Hill Mary is between endangered (by a small number of people who use it) and dysfunctional languages (in schools it is reclassified as an elective course, children prefer to speak Russian).

To preserve knowledge about the Hill Mari language as a monument in the history of human civilization, it becomes important to commit to paper all existing information about this language.

The subject of the research is the sound system of the Hill Mari language which is regarded as one of the important aspect in language education of future Hill Mari language teachers.

The aim of the research is to obtain copious information about the sound system of the Hill Mari language and it $s$ value in language teaching.

Keywords: Hill Mari, sound, phonemes, language education.

\section{INTRODUCTION}

Among thousands of functioning languages in the world, there is the language which is spoken by only about 23 thousand people in the Russian Federation. According to Consolidated Results of the 2010 All-Russian 
Population Census for the Republic of Mari El held in 2013, the Hill Mari language is spoken by 21,190 people in the Hill Mari region of the Mari El Republic, 2103 in Kozmodemyansk and 145 in Yoshkar-Ola.

In the UNESCO Red List of Languages there is a scale of six levels of endangerment presented for a clearer definition of the danger that threatens a particular language. Unfortunately, the Hill Mari language is not listed in the UNESCO Red List of Languages. It should be noted that Hill Mari currently occupies an intermediate position on this List between the 3rd degree - Seriously Endangered - there are more carriers (from two hundred to tens of thousands) and the 4th degree - Endangered - some children (at least at some age) speak the language, but their number is decreasing.

In this regard, it seems extremely important to put all available information about this language especially for school teachers or future specialists in the Hill Mari language. Development of the Hill Mari language can be conditionally divided in three periods: - preliterate; - the Soviet period; - modern (post-perestroika).

\section{OPINIONS AND DISCUSSIONS}

In this article, we analyze all the information about the sound system of the Hill Mari language in the preliterate period.

For the first time, the Mari people were mentioned in the essay of the historians of Jordan in the VI century A.D. under the name "tsarmis", "sremiskansk", which is phonetically close to "cheremis": "Dve bo cheremisy $v$ Kazanskoy oblasti..., edina ibo cheremisa ob tu storonu Volgi sidyat, promezh velikikh gor, po udoliyam, i ta slovet gornaya; lugovaya zhe cheremisa ob odnu storonuVolgi I ta sya narisaet lugovaya (Fundamentals of Finno-Ugric Linguistics, 1976, p. 4-5).

The earliest Hill Mari "written monument" can be considered a quatrain written by students of the newbaptismal school in honor of the arrival of Empress Catherine II of Russia in Kazan (The divine ceremony, held during ..., 1769). It is difficult to learn something about sounds and language in whole from that quatrain.

In 1821, the first book in Hill Mari, the Gospel, was published in St. Petersburg (The Gospel: In the Hill Mari language, 1821). It was a translation of the "Gospel of Luke" into Hill Mari, made by the Hill Mari priest A. Albinsky. It's hard to imagine how much work was done. Back in these times there was no Mari writing system. Albinsky was not a linguist and it was kind of hard for him to convey graphically specific sounds of the Hill Mari language. In the Gospel instead of ä / æ / it is written а or я: ава instead of ӓвӓ "mother", вяр instead of вӓр "place"; instead of ы / 9 / it is written y, a, э, е: кушта instead of кышты "where"; instead of ӹ /ə/ were used $u$, а, ы, у, е: кеча in place of кеӵ̈ "sun"; нына was replaced by нӹнӹ "they" (The Gospel: In the Hill Mari language, 1821).

Incorrect spelling, of course, caused great difficulties in reading. On this occasion, the Estonian linguist M. Weske put it this way: "... it would be very surprising for (Hill Cheremis) to understand the wrongly written text" (Weske, 1889, p. 39). However, translation of the Bible let priests successfully conduct services in the Hill Mari language.

In 1828, A. Albinsky was appointed as a teacher of the Mari language at the Kazan district school, where he had worked until 1830. At the same time, the commission of theological schools was entrusted with organizing a translation of the brief catechism "The Begins of the Christianity or a Brief Sacred History" into the Tatar, Chuvash, Udmurt and Mari languages with the enclosure of primers.

In addition to translating, A. Albinsky also compiled a supplement, "Primer for Learning to Read in Cheremis" that was 6 pages long. The book was printed in 1832 by the Kazan University Printing House under the title "The Begins of the Christianity or a Brief Sacred History and a Short Catechism in the Cheremis Language of the Hill Dialect with the Addition of Short Reading Rules” («Nachatki hristianskogo ucheniya ili kratkaya svyashchennaya istoriya i kratkij katekhizis na cheremisskom yazyke gornogo narechiya s prisovokupleniem kratkih pravil dlya chteniya»).

In this primer A. Albinsky introduced the Mari alphabet for the first time which was a great achievement for

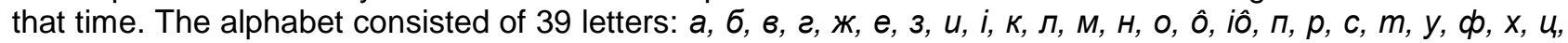

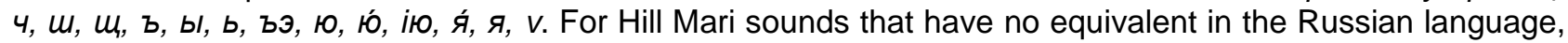
he created new characters: $/ \varnothing /-\hat{O}, / \mathrm{y} / \underline{-\wp}, / ə /-i \hat{0}, / æ /-я$. This alphabet could not fully reflect the peculiarities of the Hill Mari phonetic system. A. Albinsky was not a linguist and there were no written sources, so he could not establish an inventory of phonemes of the Hill Mari language. In this regard, he did not always use the signs introduced by him consistently to indicate a particular sound. For example, for sound $\ddot{\mathrm{b}} /$ / / he introduced the letter iю, but in his translations this sound was transmitted by $и, ы$, а: киль instead оf кӥл: "string"; тыда instead of тӹдӹ "he". 
A. Albinsky's papers played a positive role in attracting the attention of foreign scholars to Mari languages. In 1841, the paper of the German linguist G. Gabelenz "Vergleichung der beiden Tscheremissischen Dialekte" was published and it was dedicated, by his definition, to the comparison of the characteristics of Meadow and Hill Mari dialects of the Mari language (Gabelenz, 1841). As a comparison material, Gabelenz took published in 1775 by the Russian Academy of Sciences under the title "Works belonging to the grammar of the Cheremis language" (Meadow dialect) and the translation of the "Gospel" (Hill Mari dialect) made by A. Albinsky (Pucek-Grigorovich, Sochineniya, prinadlezhashchie k grammatike cheremisskogo yazyka, 1775; Gospel: In the Hill dialect, 1821). The research of G. Gabelez was based on a comparison of the imperfect translation of the "Gospel" and the "Works ...", where the phonemic composition of the Meadow Mari dialect was also inaccurately displayed. In this regard, it is difficult to identify from this work a relative representation of phonemes of Hill Mari and Meadow Mari dialects.

In Finland, 1845, the elementary grammar book of the Mari language by M. Castren was published in Latin (Castren, Elementa grammatices tscheremissoe, 1845). To write his grammar book, he used translations of the Gospel and the Apocalypse. He also did not know Mari dialects and, apparently, these imperfect translations prevented him from presenting a more or less correct description of the sound system of Mari languages. In the "Cheremis language" he found 8 vowels: $a, e, i, o, u, y, a, o$. He was not able to detect the presence of end of his grammar book Mari-Latin dictionary was presented, where a little bit inaccurate representation of the sounds of the Mari dialects was shown. However, it should be noted that M. Kastren designated Mari sounds with letters and signs much more correctly than anyone before. M. Castren had a small section devoted to the stress in Mari words (Castren, Elementa grammatics tscheremissoe, 1845, p. 8). He was the first among the researchers of the Hill Mari language, who clearly spoke about the fixed position of the stress in the Hill Mari.

In 1847, the Finnish scholar F. Wiedemann published Versuch einer Grammatik der tscheremissischen Sprache where he wrote: "It is difficult to imagine the sound of speech from a sign and it is doubly difficult because the sounds are depicted in Russian (Wiedemann, Versuch einer Grammatik der tscheremissischen Sprache, 1847, p. 8). Unlike other researchers, F. Wiedemann managed to listen to one Cheremis live speech. F. Wiedemann used in his work a more advanced notation of words and introduced a soft sign ('): l', $n$ '. If in the "Gospel" there was scholja "younger brother", Wiedemann wrote it as schol'a. A curious remark about stress Wiedemann noted that in Hill Mari the first syllable was not always stressed, as in Finnish and Estonian(Wiedemann, Versuch einer Grammatik der tscheremissischen Sprache, 1847, p. 20). Affixes can be emphasized. He thought that the stress intensifies on a vowel before a simple consonant, decreases before a double consonant, as in German. For example, kol9št9n was pronounced as / kol/9št9n /, and /koo/9št9n/.(It should be noted that the Hill Mari accent is not characterized by any "intensifications" before consonants. In general, it is difficult to understand what F. Wiedemann meant under "intensification".

In 1889, M. Weske (a professor in Kazan University) published a work "Studies on the Dialects of the Cheremis Language" (Weske, Research on Dialects of the Cheremis language, 1889). In the summer of 1887, M. Weske made a long trip to Hill and Meadow Maris. During this trip, he revealed the differences and common features of Hill Mari and Meadow Mari dialects in phonetics, grammar and vocabulary. M. Weske noted that in some cases the difference between the dialects "is the difference in vowels at the beginning of a word". For example, in the Hill Mari dialect - valem / válem /, in Meadow Mari - volem / volém / "go down"; cup /sir/ - cэp /ser/ "shore" (Weske, Issledovanie o narechiyah cheremisskogo yazyka, 1889).

In his work, M. Weske gave a complete system of vowels of the Hill Mari language for the first time. He writes "Cheremis language, namely the Western dialect (western M. Weske calls hill and north-western

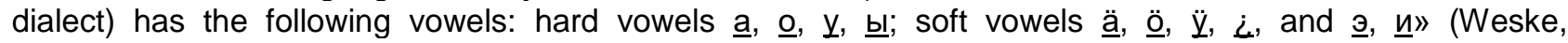
Issledovanie o narechiyah cheremisskogo yazyka, 1889, p. 8). M. Weske revealed sounds the Hill Mari language. Although M. Weske did not give a full articulatory description of vowels, his work was the first where all vowel phonemes of the Hill Mari dialect were revealed and some elements of the articulatory description of sounds were given.

M. Weske first revealed the existence of the well-known law of harmony of vowels in the Hill Mari dialect: “...

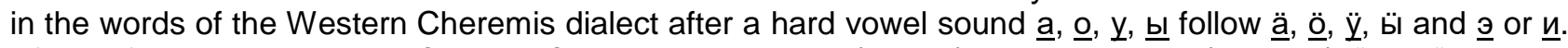

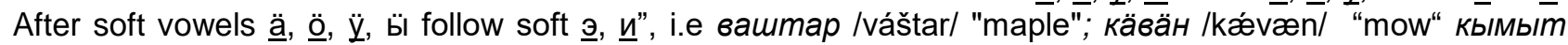
/kыmыt/ "three", нӹлӹ̈m /nálət/ "four"( Weske, Issledovanie o narechiyah cheremisskogo yazyka, 1889, p. 10).

Very careful recordings of Hill Mari sounds were made by the Finnish scholar G. Ramstedt (Ramstedt, Bergtscheremissische Sprachstudien, 1902). He made a number of expeditions to collect the material from 
Hill Mari people. In the summer of 1898 he spent three months in Tushnaly village of Vilovatov volost (now it is the Vilovatov rural village of the Gornomariysky district) collecting the richest material for studying the Hill Mari dialect, recorded from the native speakers. The texts written by him in phonetic transcription reflected the subtle peculiarities of the Hill Mari language.

G. Ramstedt subdivided Hill Mari vowels into two groups: 1) full, vigorously articulated and 2) reducible, depending on neighboring sounds. According to our instrumental research, there are no complete and reduced vowels in Mari languages.

According to G. Ramstedt, the stress in the Hill Mari dialect is expiratory and musical. The emphasis, as a rule, lies on the penultimate syllable and "in general, the stress is very weak ... As for the musical stress, it should be noted that the last syllable of interrogative words is usually very high, sometimes rises above the main tone by an entire octave" (Ramstedt, Bergtscheremissische Sprachstudien, 1902, p. 12).

G. Ramstedt's remarks on reduced vowels, their duration and stress were of particular value for the study of the Hill Mari phonetics. Of course, having modern experimental phonetics we have more realistic interpretation of certain phonetic characteristics.

In the 20th century, the Finnish ethnographer U. Wichmann and the Hungarian scientist Ö. Beke studied the Hill Mari dialect. The value of Y. Wichmann's works lies in the fact that the texts he collected and recorded in phonetic transcription allow us to compare different dialects: Kozmodemyansk, Yaransk, Urzhum and Malmyzh dialects (Wichmann, Volksdichtung und Volksbräuche der Tscheremissen, 1931).

The Ö. Beke's research was focused on phonographic and gramophone speech recordings of war prisoners and people of various Finno-Ugric ethnic groups who were in Hungary during the First World War. Hill Maris were among them. From the Ö. Beke's texts we can conclude that he accurately reflected the modifications of sounds in the flow of speech, e.g, /əðərämäšən up ${ }^{\phi}$ šə kúžы dä ыšыžы kə́tək/ "long hair and short wit"»(Beke, Volksdichtung und Gebräuche der Tscheremissen (Maris), 1951). Neither Ö. Beke nor U. Wichmann described Hill Mari sounds.

\section{CONCLUSION}

The authors of the article reviewed all sources related to the Hill Mari sound system in the period from 1821 to 1920. The researchers of the Hill Mari language did not distinguish between the "dialect" and "language". However, they clearly indicated the division into Hill Mari and Meadow Mari.

The forced introduction of Orthodoxy in the Mari territory played a positive role: to accelerate the introduction (it must be borne in mind that minor peoples of Russia were illiterate and few of them spoke Russian) priests began to translate the Bible into the different languages, including Hill Mari. An orthodox priest, who spoke Hill Mari first translated the Gospel into the Hill Mari language, created alphabet and ABC-book for Hill Maris. Despite the fact that the new alphabet was not complete and the translations were difficult to understand, they played a positive role for conducting divine services in Hill Mari.

Another positive thing was the fact that translations of the Gospel Book and other sections of the Bible attracted the attention of German, Finnish, Hungarian scholars. Some studied translations into the Hill Mari language, while others made expeditions to the Hill Mari territory. Their writings contain valuable comments on the sound structure of the Hill Mari language such as fixed stress, the harmony of vowels, etc.

Thus, since 1821 all studies on the Hill Mari language had served as the basis for the creation of the official Hill Mari alphabet and depicting sound system.

\section{ACKNOWLEDGEMENT}

This research was financially supported by the Russian Foundation of Basic Research (Grant NO. 20-01200481 A).

\section{REFERENCE LIST}

Weske, M. (1889). Issledovaniya o Narechiyah Cheremisskogo Yazyka.

Gabelenz, H.C. (1841). Vergleichung der beiden Tscheremissischen Dialekte.

Castren, M. (1845). Elementa grammatics tscheremissoe. 
Proceedings of ADVED 2020- 6th International Conference on Advances in Education 5-6 October 2020

Ramstedt, G. (1902). Bergtscheremissische Sprachstudien.

Wichmann, Y. (1931). Volksdichtung und Volksbräuche der Tscheremissen.

Beke, Ö. (1951). Volksdichtung und Gebräuche der Tscheremissen. 